\title{
Hector McGillivray, Malraux et la révolte irrationnelle. Politique, histoire et culture
}

\section{Emanuele Kanceff}

\section{Q OpenEdition}

1 Journals

\section{Edizione digitale}

URL: https://journals.openedition.org/studifrancesi/39783

DOI: 10.4000/studifrancesi.39783

ISSN: 2421-5856

\section{Editore}

Rosenberg \& Sellier

\section{Edizione cartacea}

Data di pubblicazione: 1 décembre 2004

Paginazione: 409

ISSN: 0039-2944

\section{Notizia bibliografica digitale}

Emanuele Kanceff, «Hector McGillivray, Malraux et la révolte irrationnelle. Politique, histoire et culture», Studi Francesi [Online], 143 (XLVIII | II) | 2004, online dal 30 novembre 2015, consultato il 19 mai 2021. URL: http://journals.openedition.org/studifrancesi/39783 ; DOI: https://doi.org/10.4000/studifrancesi. 39783

Questo documento è stato generato automaticamente il 19 mai 2021.

\section{(c) (1)}

Studi Francesi è distribuita con Licenza Creative Commons Attribuzione - Non commerciale - Non opere derivate 4.0 Internazionale. 


\title{
Hector McGillivray, Malraux et la révolte irrationnelle. Politique, histoire et culture
}

\author{
Emanuele Kanceff
}

\section{NOTIZIA}

HECTOR MCGILIVRAY, Malraux et la révolte irrationnelle. Politique, histoire et culture, Paris, Lettres Modernes Minard, 2000 («Archives des lettres modernes», 279), pp. 121.

1 La prima parte di questo libro cerca di ricostruire la nozione della storia che ispira l'opera e l'evoluzione di Malraux e il suo pensiero politico, che viene messo a confronto con il pensiero marxista. Questa evoluzione della sua coscienza politica è seguita attentamente attraverso le varie fasi della storia d'Europa e del mondo, alle quali corrispondono stagioni variegate del suo pensiero.

2 La seconda parte del libro analizza invece la concezione che Malraux ebbe della cultura e della sua missione, dei rapporti tra l'artista e il potere, poi tra la coscienza artistica e la vita sociale.

3 Contrariamente a quanto comunemente si crede, che siano i grandi romanzi impegnati a trasmettere l'eredità più grande ed immortale dello scrittore francese, l'A. è invece propenso a credere che la parte più importante di questa eredità consista nei suoi scritti sull'arte plastica e nei suoi Antimémoires, senza per questo dimenticare la sua critica letteraria né la funzione dirompente che ebbero talvolta i suoi scritti polemici. Questa convinzione è stata gravida di conseguenze perché ha convinto l'A. della necessità di dare i più ampi limiti testuali al suo studio. 